\title{
Governance as Catalyst to Sustainable Tourism Development: Evidence from North Cyprus
}

\author{
Habib Alipour \\ Associate Professor PhD. Eastern Mediterrnean University \\ School of Tourism \& Hospitality Management, Turkey \\ E-mail: habib.alipour@emu.edu.tr \\ Ruchan Kayaman Vaziri \\ Assistant Professor PhD. Eastern Mediterrnean University \\ School of Tourism \& Hospitality Management, Turkey \\ E-mail: ruchan.kayaman@emu.edu.tr \\ Elena Ligay \\ Research/teaching Assistant. Eastern Mediterranean University \\ School of Tourism \& Hospitality Management, Turkey \\ E-mail: elena_ligai@hotmail.com
}

Received: July 22, 2011

Accepted: August 31, 2011

doi:10.5539/jsd.v4n5p32

\begin{abstract}
This study argues that sustainable tourism planning cannot be implemented unless institutions restructure their behaviors (i.e., the formal policy process) in close cooperation with the industry's stakeholders (i.e., informal elements). What is missing in the case of North Cyprus is the concept of governance as distinct from government, which began to manifest when government became an organization apart from citizens rather than a process (Plumptre and Graham, 1999). Therefore, this study investigates the institutions that compromise the policy-making process of governance and its inferential outcomes for the purpose of achieving sustainability. Using a qualitative research strategy, therefore a semi-structured interview questionnaire was administered. Interviewees were targeted within the relevant institutions based on purposive and snowball sampling. The underpinning conceptual framework that guides the methodology is based on the Environmental Sustainability Index (ESI, 2005) with emphasis on the component of 'social institutional capacity': governance. The study revealed the need for an institutional overhaul with an embedded process of governance as a new institutional culture. Furthermore, an institutional approach should accompany new practice methodologies for the way the tourism sector consumes places, produces products, and applies a conservation-based ethic to the natural and built environment.
\end{abstract}

Keywords: Sustainability, Governance, Institutions, Tourism, North Cyprus

\section{Introduction:}

The field of tourism has attracted considerable attention due to its economic benefits and its status as among the fastest-growing industries in the world. This can be verified by the enormous amount of data on the economic performance and the economic impact of tourism (Balaguer and Cantavella-Jorda, 2002; Lee and Chang, 2008). Economically tourism has been encouraged and supported by international organizations to facilitate growth around the world (WTTC, 2004; WTO, 2008). However, this myopic view of tourism's economic impact has generated a flood of literature about the side effects of this impact; specifically tourism's negative impact on the social and environmental aspects of various communities and destinations (Gunn with Var, 2002; Burns, 1999; De Kadt, 1979; Hall, 2008). 'Despite the potential of tourism as a development tool, and the worldwide mushrooming interest in tourism-based poverty alleviation initiatives, the relationship between tourism and poverty alleviation largely remains terra incognita among tourism academics' (Zhao and Ritchie, 2007: 10). These concerns regarding sustainability have led to the question, is the 'business as usual' approach to tourism 
development sustainable? The answer to this question lies at the core of this study, which aims to examine the nature of institutions' efforts and commitments to initiate the process of sustainable tourism planning.

The study assumes that the public policy environment should be conducive to 'governance' as a prerequisite to the process of sustainable development. The study builds upon the definition of 'governance' conceptualized by Osborne and Gaebler (1993), who call for a revolutionary restructuring of the public sector and distinguish a new, entrepreneurial form of government:

'Governance is the process by which we collectively solve problems and meet our society's needs - government is the instrument that we use. Governance encompasses not just government, but also the private sector and civil society (individuals and groups) and the systems, procedures and processes in place for planning, management and decision-making' (p. 24).

In summary, this study focuses on the nexus of sustainability and governance in the context of tourism development and planning in the highly fragile and limited environment of North Cyprus. The aim of this study is to explore the behavior of relevant institutions and gauge the degree of their stated commitment to governance for sustainability-based decisions as a strategy for change. The tripartite scenario of 'tourism', 'sustainability', and 'governance' is a broad spectrum that cannot be addressed in one article. Thus, the emphasis of this study is on how governance manifests through policy processes to implement a sustainable tourism industry.

Although agreements and declarations on sustainable development (including limits to growth; world conservation strategy; our common future; local agenda 21; world summit on sustainable development; Rio +10 ; Lanzarote Charter for Sustainable Tourism; etc.) have been desired and signed by policy makers worldwide, few of these agreements have actually outlined a measurable policy (Dodds, 2007). The problems of accountability, priority, coordination, integration, local participation, favoritism, nepotism, and shortsightedness are common impediments to implementing and measuring 'sustainability'. An important dimension of the conceptual framework of this study is positioning governance not as a metaphor but as a practical approach toward an institutional movement for sustainable tourism planning. Building on this theme, it is plausible that institutions, social relationships and culture matter in development (Economist, 1997). Despite the rapid economic growth and urbanization in North Cyprus during the past decade, the issue of 'sustainability' has remained an alien concept for policy makers. This attitude manifested in haphazard urbanization, lack of land use plans, air and water pollution, insufficiency of infrastructure (including sewers and waste disposal), traffic congestion, dwindling green space and fertile agricultural land, coastal damage, and an absolute lack of waste management (Alipour et al., 2007; Yorucu and Keles, 2007).

\section{Sustainability and Governance Nexus}

\subsection{Sustainability}

The concept of 'sustainable' development is not new, notwithstanding its late entrance into the tourism development spectrum (Hunter, 1997; Choi and Sirakaya, 2006). The concept has been embedded in almost every discussion of resources, land use, development, construction, energy, environment, consumption, and education. Within the 'tourism' arena, the concept has been supported through the Product Life Cycle (PLC) and Doxy's Irridex models (Butler, 1982; Doxy, 1975). These models demonstrated a new perspective on nature and the dynamism of the tourism industry both spatially and temporally.

Sustainable tourism development (STD) began to gain ground through the realization of the environmental impact of tourism (Jones and Munday, 2007; Collins et al., 2007) and its ecological footprint (Hunter and Shaw, 2007; Gössling et al., 2002), whereby visitors' impact could affect the economic benefits of tourism, especially for the local people and remote destinations. Along with the spatial changes and resource consumption of the tourism sector, rapid urbanization and land use practices contributed to doubt about the longevity of destinations for the welfare of future generations (Hunter, 2002; Huijbregts et al., 2008). Numerous challenges, including global warming, economic recession, political conflict, population growth, and the uncertain future of fossil fuels as a main source of energy, demand a new paradigm for planning and marketing tourism products worldwide.

The tourism sector is experiencing an evolutionary transformation that demands a revolutionary approach to reforming its management regime. Interestingly, the 'triple bottom line' scenario, which can be paraphrased as 'environmentally, economically, and socially sustainable industry', is not limited to tourism; rather, it is a paradigm shared across numerous industries and development projects that deal with land, natural capital, and production (Krajnc and Glavič, 2005). The 'triple bottom line' model has been enhanced with the addition of two more domains to the 'sustainability' paradigm: 'public policy' (i.e., government or public rules/regulations) and 'technological' (i.e., appropriate, sustainable) (Steward and Kuska, 2010). 
The enhanced paradigm aims to achieve integrated resource management. Resource management, in this context, connotes the building of a sustainable socio-economic structure based on a new approach to the 'environmental', 'economic', 'social/cultural', 'public policy', and 'technological' domains. This is a new paradigm for design. In the context of governance, this paradigm can be implemented as a new approach to the functioning tourism system, which encompasses concerns for the implications of land use, ecology, society, economy, and culture for future generations.

The urgent need for a sustainable approach to tourism planning and development has been a frequent subject of international consideration, culminating in the CSD7-Tourism and Sustainable Development UN session, which ended with the World Summit on Ecotourism in 2002 (Roe and Khanya, 2001). In this report, the role of NGOs was stressed as an important dimension of governance for sustainable development (http://www.world-tourism.org/sustainable/doc/CSD7-99-WTOcontribution.pdf). However, there is nothing automatic about a society managing the transition to sustainability (Sacks, 2008). The path to sustainability demands new institutional behavior beyond conventional economics. This is a novel approach to sustainable development and an impetus for a fundamental rethinking that will transcend the top-down approach to the tourism policy-making process (Rist, 1997). One example of such rethinking is the emergence of the sub-discipline of ecological economics. Ecological economics claims to address the shortcomings of conventional economic analysis, this is achieved by paying attention to how the ecosystem which impinges on the economic system' (Loomis, 2000, p. 894). Notwithstanding the broadness of the concept of sustainability and a certain level of ambiguity (Helmy, 2004; Loomis, 2000) regarding its practicality and measurement, this concept is still second to none in terms of our understanding of the long-term maintenance of valued [quantifiably] environmental resources in an evolving human context (ESI, 2005).

\subsection{Governance}

The concept of governance can be interpreted as a mutation to a higher level within social structures (i.e., the radical transformation of institutions) (Osborne and Gaebler, 1993; North, 1998). At the same time, governance is an embodiment of a holistic approach to planning and development in which institutions transform themselves toward sustainability as a process and as an objective (Stanhope, 2000; Kates et al., 2005). Regarding the institutions, the Nobel Laureate Douglass C. North stated, "I wish to assert a much more fundamental role for institutions in societies; they are the underlying determinant of the long-run [sustainable] performance of economies" (as cited in Aron, 2000, p. 99). However, the role of institutions is not necessarily concretized; rather, this role can be restructured to respond to new complexities and demands (i.e., sustainability). Therefore, governance becomes a metaphor to speak of shifting the conventional role of institutions and shrinking the role of the state. In reference to these shifting roles, Kooiman (2003) stated:

'Responses to diverse, dynamic and complex societal issues [including planning and development] require approaches involving previously uninvolved partners, looking not only at the market [and its invisible hands] as seems to have been an almost universal response in recent years, but also looking at 'civil society' actors, as serious governing partners. The 'why' of modern governance can be best explained by an awareness that governments are not the only actors addressing major societal issues; that besides the traditional ones, new modes of governance are needed to tackle these issues' (p. 3).

To further articulate the notion of governance, Giddens argues that the political processes of the past are insufficient to deal with the social complexities of the future. He introduces the challenge of integrating ecological problems into social democratic politics:

"The notion of sustainable development fits well with the broader one of ecological modernization (defined as partnership in which governments, businesses, moderate environmentalists, and scientists cooperate in a restructuring of the capitalist political economy along more environmentally defensible lines). Due to its fuzzy nature sustainable development should be more a guiding principle than precise formula. Experts cannot be relied upon automatically to know what is good for us, nor can they provide us with unambiguous truths, they should be called upon to justify their conclusions and policies in the face of public scrutiny" (as cited in Burns, 2004, p.29).

Despite the popularity and the impreciseness of the concepts of governance and sustainability, they are presented as inescapable paradigms of development and planning in the 21 ${ }^{\text {st }}$ century (Rhodes, 1996; Gamble and Weil, 1997; Hunter, 1997; Segovia, 2010). Generally speaking, governance and its processes are participatory, consensus oriented, accountable, transparent, responsive, effective, efficient, equitable, inclusive and follow the rule of law. Governance assures that corruption is minimized, the views of minorities are taken into account and 
the voices of the most vulnerable in society are heard in decision-making. Governance is also responsive to the present and future needs of society (Onga, 2007).

Based on the aforementioned themes, governance has been suggested as a mechanism to pave the institutional path towards a socio-political environment conducive to sustainability. It is a shift that facilitates a decision-making environment conducive to the integration of formal and informal institutions, which are essential to achieving sustainability. This mechanism is described as 'networks (involving public and private organizations, civil society movements, community organizations, co-operations, etc.)' (Penker, 2009, p. 949).

'Tourism' is the backbone of the economy for an island state, and it cannot remain at the mercy of perspectives armed with the notion of 'boosterism' (i.e., laissez-fair approach) (Hall, 2008). Its powerful impact on ecosystems, both directly and indirectly, demands a new approach to tourism planning and management (Wearing and Neil, 2009). Therefore, Burns (2004) eloquently noted:

'Ecological problems are not viewed as "acts of nature" but as a result of unchecked and weakly regulated capitalism. With the growth of information flows such as satellite television and the internet, corrupt politicians become more easily exposed, which has contributed towards a growing distrust of politicians alongside a parallel growth in environmental concern. Tourism is a prime user of the natural environment. The industry presents a prime opportunity for jobs, investment and community activity to work in partnership to use and not abuse the environment. Such orientation is simply ensuring the long-term availability of a natural asset in the form of a consumer commodity' (p. 30).

Various empirical studies have focused on the relationships between the composition of governance within institutions and the resulting progress towards sustainability in developing countries. For instance, the combination of a weak institutional structure and fractionalization within the governing elite (i.e., absence of governance) is correlated with slow growth and haphazard development (Tornell and Lane, 1999). Kaufmann and Kraay (2008: 1) have measured governance and institutional quality as trajectories for sustainable development. They state, 'Most scholars, policymakers, aid donors, and aid recipients recognize that good governance is a fundamental ingredient of sustained economic development'.

\section{The conceptual model: A synthesis}

This study assumes that two dimensions of the political economy of North Cyprus can be empirically tested to establish that institutions have remained archaic and that the governance process has never been given an opportunity to take hold. First, this study (re)evaluates perceptions of institutions regarding planning and development; these perceptions have remained static for the last three and a half decades. Therefore, the sustainable tourism development initiative, in the case of North Cyprus, is fundamentally an institutional issue. This issue manifests through governance dimensions in terms of the state's ability to implement sound policies (i.e., sustainable measures through a regulatory burden) and solicit the involvement of citizens and NGOs to spearhead the goals of sustainability (World Bank, 1997; Acemoglu et al., 2001; Acemoglu and Johnson, 2003; Aron, 2000). Second, the processes of tourism development and urbanization, environmental quality through conservation, the efficacy of laws/regulations, and the shift towards green technologies (in this case, the issue of energy sources) are also explored. The conceptual model (see Figure 1) has been instrumental in shaping the study's conceptual framework towards sustainability through governance in the context of a transition management model (Kemp et al., 2005), which presented a practical as well as an adaptive policy model that will lead to sustainability within the reach of society.

The conceptual model that follows is not a prescription; rather, it is a scheme that illustrates the absence of governance towards sustainability in the context of the tourism sector. In the meantime, it calls for a new institutional approach to uphold ecological restoration through adaptive management. The adaptive management cycle can test and measure the processes and stages of governance for sustainability through ecological restoration. However, this cannot be achieved unless the cycle of actions

\section{Figure 1. insert here.}

offered by adaptive management is in place and pursued. As illustrated in the model, governance for sustainability becomes a catalyst for commencing a rigorous process of environmental management (Murray and Marmorek, 2004). First, this type of management refocuses on approaches and behaviors for which the long-term health of the ecosystem and society is the goal. This will not be an easy enterprise (metaphorically speaking, 'no pain, and no gain'). On the other hand, the choices are limited, and sacrifices must be made. As Gibson stated: 
"Sustainability calls for prudence and adaptability, preferring safe-fail over fail-safe technologies, seeking broadly comprehensible options rather than those that are dependent on specialized expertise, ensuring the availability and practicality of backup alternatives, and establishing mechanisms for effective monitoring and response" (as cited in Kemp et al., 2005, p.16).

The model is also developed based on the authors' decade and a half of experience and observation with the conduct of institutions and the behaviors of influential policy makers in the system. There is a belief that the time has arrived for change towards practical processes rather than simply an ongoing theorization of the concept of sustainability.

The model is feasible and practical because all the elements are in place, to some extent; this is a realistic approach to the particular environment of North Cyprus. The main challenge is how to initiate a chain reaction in the institutions' behaviors to jump-start a shift towards sustainability. Putting the concept of governance for sustainability in the context of the tourism industry has not occurred by chance. The tourism industry is characterized as a multidimensional and non-linear sector (Gunn with Var, 2002; Hall, 2008) that warrants a flexible management approach to integrate and evaluate five domains of sustainability (social/cultural, environmental, economic, public policy, and technological) within the framework of trust building, institutional linkages, and bridging organizations (Folke et al., 2005; Duxbury and Dickinson, 2007).

The role of the five domains of sustainability in guiding the study's conceptual framework will be discussed in the research methodology section as research tools or analytical frameworks. Finally, the tourism sector remains a major force with a long-term impact on the environment and society. The model factors in two levels of microand macro-environmental elements that are expected to reach a consensus for governance towards sustainability. In this regard, Dinica (2009, p. 591) described 'the vertical and horizontal coordination of actors, which can be realized by means of formal or informal institutional structures/committees, or specific policy instruments (guidelines or monitoring systems targeted at public authorities)'. The model is also a collaborative process. This collaborative action between the macro/formal and micro/informal levels generates networking processes, which result in changing institutional behaviors from a rigid pattern (for example, the case of North Cyprus) to an adaptable pattern.

As the model demonstrates, this process also legitimizes both contraction and convergence (e.g., greening economic development/green new deal) (http://policy.greenparty.org.uk/rops/ropsec.pdf\#2) towards sustainability's five main domains. If this is the process, then the purpose of the model is to promote human systems in balance with the natural environment (Steward and Kuska, 2010). It is also possible to measure the degree of achievement for each sustainability domain. Furthermore, the conceptual approach of the study is framed by 'governance for sustainability' in the context of tourism industry behavior. 'Governance for sustainability' includes a holistic awareness and responsible values that move away from short-term gains (which are associated with mass tourism) and focus on imaginative, proactive design and redesign approaches to ecological wellbeing and the sustainable management of natural resources (Bosselmann, 2008; Edgell et al., 2007).

\section{The study site}

The island of Cyprus is the third-largest island in the Eastern extreme of the Mediterranean Sea. Since 1983, two communities have existed in Cyprus. One state, the Republic of Cyprus (referred to as the Greek side or South Cyprus), is recognized internationally and claims to be the legitimate (de jure) government of the entire island. However, it has no power or control over one third of the island in the north. The latter state, or North Cyprus (officially known as the Turkish Republic of North Cyprus-TRNC), is wholly characteristic of a microstate and is not recognized by any other country but Turkey (Mehmet and Tahiroglu, 2002). The island has been divided since 1974, and the two separate parts were demarcated by a green line and enforced by the United Nations peace-keeping forces. Cyprus lies $65 \mathrm{~km}$ from Turkey's southern coast. Other neighboring countries include Syria $(97 \mathrm{~km})$, Lebanon $(108 \mathrm{~km})$, Egypt $(370 \mathrm{~km})$, Israel and Greece. The total area of the island is approximately 9,252 sq. km, but North Cyprus covers a total area of 3,515 sq. km, or nearly one third of the whole island (see Figure 2) (http://northcyprusonline.com). In the spring of 2003, a formal agreement between the two communities officially opened the borders to allow travel between two sides (Webster and Timothy, 2006). With a population of nearly 300,000, mainly of Turkish origin, the history of Turkish Cypriots on the island goes back to the early $16^{\text {th }}$ century with the defeat of the Venetians by the Ottoman Empire.

\section{Figure 2. insert here.}

North Cyprus has been recognized as a political entity by the latest United Nations' Annan Plan, which bears witness and testifies to its recognition as either a federated or confederated member of the island on equal 
footing with the South (Lacher and Kaymak, 2005). Despite the failure of the Annan Plan to solve the Cyprus conflict, it legitimized Turkish Cypriots while alerting the world to the fact that North Cyprus is a distinct culture with a people deserving of their own independent way of life. 'Under the Annan Plan, a United Republic of Cyprus would have become a member of the European Union, as an indissoluble partnership with a federal government and two equal constituent states, the Greek and Turkish Cypriots' (Altinay and Bowen, 2006, p. 941).

As an island surrounded by the Mediterranean Sea, North Cyprus has capitalized and structured its economy on tourism as the main sector. Its climatic condition is highly conducive to sun, sea, and sand tourism (see Table 1 for the tourism movement in North Cyprus), ensuring that tourism will continue to play a significant role in its economic development and relationships with the world. This has also been reflected in the recent expansion of the accommodation sector and residential tourism development, particularly along the coastal areas (Mehmet and Yorucu, 2008).

\section{Table 1. insert here.}

\section{The study method:}

We applied a qualitative research approach to examine the institutions and their commitment to the process and objectives of sustainable tourism development. The study focused on exploring governance for sustainability, emphasizing the tourism sector with the following goals:

- To acquire appropriate knowledge regarding sustainable tourism and tourism planning by examining the relevant literature.

- To consider the current situation of the tourism sector in North Cyprus and identify the stakeholders and decision makers that plays a role in tourism planning.

- To gain in-depth knowledge about how sustainability is perceived, understood and applied toward tourism planning and development.

- To explore the main characteristics of the institutions responsible for tourism planning.

- To determine whether the sustainability paradigm has a place in the structure of institutions and how it affects actors' behavior.

- To identify and explore the extent of governance as it has been defined and understood.

Qualitative method was chosen as a research strategy which usually emphasizes words rather than quantification in the collection and analysis of data and that predominantly emphasizes an inductive approach to the relationship between theory and research, in which the emphasis is placed on the generation of theories from empirical analysis. It prefers to place emphasize on the ways in which individuals interpret their social worlds. "This method embodies a view of social reality as a constantly shifting emergent property of individuals' creation. At best, it achieves generation of theory and it is highly based on interpretivism and constructionism (i.e., asserts that social phenomena and their meanings are continually being accomplished by social actors) in contrast to quantitative method" (Bryman, 2004, pp. 19-20).

This study uses inductive approach in order to explore the concept of sustainable tourism development within a hypothetically revised institutional framework known as 'governance' in the specific case of North Cyprus. For this purpose, an adaptive/transitional/reflexive planning process has been intended to guide the conceptual analysis throughout this study. When the aim and objectives of the study is taken into account, inductive approach opens the path to various scholarships including: the scholarship of discovery; the scholarship of integration (synthesis); the scholarship of practice (application) (Ghoshal, 2005).

In order to fulfil the objectives of the research, focused (semi-structured) interviews were conducted with 15 respondents. Respondents come from multiple backgrounds with first-hand experience regarding the decision making process in the context of respective institutions as parliamentarians, civil servants, planners, managers and academicians, member of NGOs, and ecotourism operators. They were interviewed by using questionnaires compose of thirty open ended questions. All the responses and discussions were recorded, which is highly essential for compiling data for analysis.

The following principles were adhered to in order to uphold the strength of the process: a positive rapport was established between respondents and the interviewer; high validity established through openness or lack of giving direction, instead allowing interviewee to reveal and speak for themselves; complex questions and issues were clarified; and avoiding pre-judgment, whereby the interviewer did not reveal what is important or unimportant information via pre-set questions. Also, a purposive sampling method was applied which is within 
the domain of non-probability sampling and was supplemented by means of snowball/chain-referral sampling. This method is highly utilized in this type of research where the study's purpose and the researcher's knowledge of the population guide the process. If the study entails interviewing a pre-defined and visible set of actors, the researcher may be in a position to identify the particular respondents of interest and sample those deemed most appropriate (Tansey, 2007).

This type of sampling method is also known as convenience or accidental sampling. This is in line with similar case studies where the sample size is not an important issue due to the nature of the research and the investigation. The design of the interview questionnaire was developed by sustainable development procedures recommended by European Union publications (Smeral, 1998; Leidner, 2004) , the World Tourism Organizations guideline regarding sustainable tourism development (STD) (WTO, 2004), and the 2005 environmental sustainability index (EIS), and numerous case studies that focused on sustainable tourism development and environmental quality issues. The research method has also been guided by the sustainable development model known as 'triple-bottom line' model (Dahl, 2005; Northcote and Macbeth, 2006; Burstörm and Korhonen, 2001) which sets three parameters/dimensions for any sustainable planning analysis (environment, economic and social). The model has been recently enhanced to five dimensions/ domains (Steward and Kuska, 2010) and recommended to planners, designers, environmentalists, and administrators to guide investigation of sustainable development (SD). This research has adopted/ applied the latter enhanced model as a baseline for both investigation and data analysis which two more domains have been added to the sustainable planning process (environment, economic, social/cultural, technological, and public policy/governance). See also figure 3.

Figure 3. insert here.

\section{Data analysis}

Data analysis, in this particular 'case study', necessarily involved varieties of the approaches associated with qualitative data gathering and analysis. It is fair to say that the analytical process in qualitative data analysis begins from the moment a researcher initiates the process which begins with locating the subjects which can be involved phenomenologically in the field research, grounded theory, and ethnography. Nevertheless, data analysis has been conducted through an iterative process, which means a repetitive interplay between the collection and analysis of data (characteristic of qualitative data analysis). As Bryman (2004, p. 399) noted: "this means analysis starts after some of the data have been collected and the implications of that analysis then shape the next steps in the data collection process. Consequently, while grounded theory and analytic induction are described as strategies of analysis, they can also be viewed as strategies for the collection of data as well". The use of the qualitative method was appropriate, because of the nature of this research, which, whose aim was to explore what is 'going on' in a situation regarding the concept of 'sustainability' in tourism and the related 'planning' processes. This is also conducive to research topics dealing with people, organizations and groups. Since the interview techniques have been used, including comments and ideas on the concept of the sustainability and planning and other related issues, therefore, a greater interest in the interviewee's view was at stake. To achieve the researcher's objectives, a semi-structured interview was conducted which allowed an insight into what an interviewee sees as relevant and important.

Data analysis had been furnished through recorded interviews, open coding/ recoding of the interview transcripts, and tabulation of the results. This is known as inductive reasoning where the research process will produce a theory (Feeney and Heit, 2007; Bryman, 2004) towards reinforcing the validity of 'governance' as an assumption regarding the main aim of the research.

The coding process as applied to data analysis is almost simultaneous with the data gathering; therefore, some core concepts were identified. The coding process encompasses several stages for the purpose of refinement of high volumes of data towards producing 'themes'. These stages include categorizing the data and describing the implications and details of the categories, followed by the process of breaking down, examining, comparing, conceptualizing and categorizing which are parts/bits of the coding process (Strauss \& Corbin, 1990). However, this process eventually filtered down to selective coding where the researcher systematically codes with respect to a core concept. The second step in this process is memoing, which is a process for recording the thoughts and ideas the researcher collects throughout the study. Third, integration, which provides for pulling all the detail together to establish an understandable and rational theory in relation to the data collected and compiled. These findings gradually focus on the core concepts or themes (i.e., sustainability, governance, environment, energy, ecotourism...etc). See table (2). Based on the themes which are extracted from the questionnaire through categorization/coding, data can be interpreted/analysed. This process is demonstrated in figure (4) where the 
final analysis is labelled (interpretations). Nevertheless, the process of analysis started with a fluid process of narrative data analysis and then understanding the data involving iterative listening to the recorded materials and (re)reading the notes. From this practice a researcher can elaborate upon impressions from the data. It is possible to discard some of the data as they may not add any meaning or value to the process; they can even be biased. In the next step, the focus is narrowed down to issues such as governance, institutional behaviour, energy...etc. Here the focus is on each respondent's answer to a particular issue whereby differences as well as consistencies are identified and the data from each question are rationalized (see table 2). In this process we explored the connectivity and relationship between questions pertaining to the topic or theme.

In the next step the data is categorized/coded/indexed and finally the main themes in the context of the research assumptions (domains) is formulated into ideas, concepts, incidents, or terminologies for the purpose of summarized interpretations and meanings. Responses were narrowed to 20 issues and themes that were processed against five domains for sustainability (see Table 2, Data Analysis Matrix).

\section{Table 2. Insert here.}

\section{Figure 4. Insert here.}

\section{Findings and Conclusion}

The respondents' overall views regarding 'sustainability' indicated a degree of familiarity with the concept. Whether the respondents have a deeper and more comprehensive view of the working of sustainability is doubtful. At the local level, the overall understanding and familiarity with the concept is almost absent. Respondents in the academic environment are much better informed about the concept. The respondents' participation in any international congress on sustainability was also discussed in the interviews. However, because most of these conferences are organized and attended by academics, officials and institutions are not usually keen to attend. A majority of the respondents acknowledged the significance of sustainability, but they could not comprehend how it could be applied. They did not express enthusiasm regarding reorienting themselves and their planning approaches towards this goal. In response to the question regarding the European Union Program and the EU's directives for sustainability within the member states, a majority of the respondents had immersed themselves in neither understanding nor contemplating the EU's programs. Community participation is one of the most important dimensions in achieving sustainable tourism planning and development. In the case of North Cyprus, a majority of the respondents emphasized that there should be a commitment to community participation. However, they had not been able to involve the community in the process as a dynamic aspect of governance.

In response to the question of who should be in charge of applying and implementing sustainability, respondents believed there should be experts on board within the institutions to guide the system in this direction. This is a mechanical view of the process of sustainability. Respondents were not aware that it was their responsibility within the institutions to approach the issue through an adaptive management system (Kemp et al., 2005).

Natural resources, cultural heritage, and the quality of the environment are the core aspects in the 'sustainability' discourse. The first step in this direction is the development and enforcement of laws and regulations. However, respondents were unable to discuss their views regarding the absence of laws and requirements (e.g., the Environmental Impact Assessment) or the lack of enforcement of existing laws (e.g., zoning).

Furthermore, in an environment such as North Cyprus where coastal areas are the main tourist attractions as well as important parts of ecosystems, one expects to see an integration of these fragile zones into a broader urban/regional planning scheme. The problem is exacerbated by a rapid and unplanned urbanization due to an explosion in the housing and construction sectors in the last decade (SPO, 2008; Yorucu and Keles, 2007). Since 2002 , the construction sector has become the main contributor to the GDP with a $12.2 \%$ share by 2006 , third after tourism and trade. In monetary terms, the capital investment has increased by $1700 \%$ since 2001 (SPO, 2008: 9). This is tantamount to urbanization and land use. However, the process has been devoid of any fundamental planning guidelines.

The fragile landscape and coastal zones have been subjected to haphazard urbanization. The process of rapid land development has resulted in destruction of the natural environment, such as the Kyrenia Mountains for the purpose of raw minerals for construction. The essential plans, including transportation, environmental issues, energy, disaster prevention, communication, overall infrastructure, green space, open space, public utility provision facilities, and sewer systems, have been neglected. This process and its resulting problems have been intensified by traffic and the skyrocketing rate of private car ownership. 
Governance for sustainability has remained the lowest concern on institutions' agendas. The environmental agency (Çevre Koruma Dayresi) is the most underfunded, understaffed, and trivialized agency. Witnesses have often given their opinions on the conspicuous environmental neglect and apathy through public outcry in the local newspapers (especially Kibris Gazetesi and Afrika, the most frequently read dailies).

This study focused on policy issues and institutions' roles in developing mechanisms to overcome the challenges of sustainable approaches and resource use trajectories. This dimension has been important as one of the building blocks of the sustainability index (Environmental Sustainability Index (ESI) - Social and Institutional Capacity). The findings revealed that in the case of North Cyprus, the institutional environment for sustainable tourism planning is not in place. Furthermore, institutions and underlying social patterns of skills, attitudes, and networks that foster effective responses to environmental challenges and sustainable approaches to tourism planning are improbable policy issues.

In discussions of 'institutions' and the tourism landscape, integrating different social theories can contribute to a deeper understanding of the processes and the significance of their outcomes. In relation to tourism, different scholars have applied postmodernism, structuralism, and post-structuralism to various tourism-related cases and environments (Davis, 2001; Pretes, 1995). In the case of North Cyprus, the rigidity of the institutions is assumed to be the barrier to sustainability. If the institutions' behavior is suspect, this research will benefit from the infusion of two modes of social theories: 'path-dependent' and 'lock- in' perspectives.

Historically, the institutional rigidity in the past four decades reflects a condition in which the 'path dependence' (Paul, 1994; Acemoglu et al., 2001; Jameson, 2006) scenario explains the form and function of human organizations and institutions. The 'lock-in' scenario argues that certain economies have not been able to reinvent themselves based on the dynamic new developments essential to change and progress (Martin and Sunley, 2006; Mahoney, 2001). Martin and Sunley (2006, p. 400) have synthesized three dimensions of path dependence scenarios and elaborated the outcome in the context of institutions and governance. They observe 'the tendency for formal and informal institutions, social arrangements and cultural forms to be self-reproducing over time, in part through the very systems of socio-economic action they engender and serve to support and stabilize'. Therefore, this study is aimed at exploring why institutions, particularly tourism-related institutions, have not been able to achieve historical adjustment.

We are convinced that 'sustainability' and 'governance' for sustainable tourism development are a developmental paradigm that is instrumental to achieve environmental management (WCED, 1987; Lane, 1994; Lane and Bramwell, 1999, Song and Glasson, 2010). Based on this precept, this study investigated the case of North Cyprus, where governance for sustainability was suspect. This justifiable assumption reflects an underlying issue in which tourism is the sole breadbasket, and the environment, as the main tourism product, is the main foothold towards the future. Within this framework, the research project of this study examined whether institutions are prepared to shift gears (adaptive management) towards the aforementioned new paradigm in an era of numerous environmental challenges and human wastefulness. This study discovered that environmental concerns, and thus sustainable tourism development, have been compromised by the conveniences of short-term development projects: increasing private transportation, the lack of any kind of recycling, environmental education or legislation, the absence of conservation or commitment, the lack of coastal management or waste management, and dependency on fossil fuels while the sun shines every day of the year are some of the incriminating points that defy progress towards sustainable development. The study has also revealed that the present outlook and culture of the institutions is devoid of any movement (or any thought) towards a shift in the direction of governance. This can be explained by the historical fact that North Cyprus's institutions, since the partition and separation from the rest of the island, have remained parochial at best, highly rigid and out of touch with the realities of present-day environmental challenges and their implications for sustainability (Alipour and Kilic, 2005).

At the same time, the peculiar political economy of North Cyprus, in the context of the 'Cyprus conflict', has not been conducive to the sort of political environment that fosters formidable strategies to deal with issues relevant to sustainable tourism development. In the context of institutional hysteresis, these findings validate 'the tendency for formal and informal institutions, social arrangements and cultural forms to be self-reproducing over time, in part through the very systems of socio-economic action they engender and serve to support and stabilize' (Maritn and Sunley, 2006: 400). Therefore, sustainable design in tourism should involve and incorporate the five domains to promote human systems in balance with the natural environment. 


\section{References}

Acemoglu, D., and Johnson, S. R. (2003). Unbundling Institutions. Retrieved 25, January, 2011, from: http://www.nber.org/papers/w9934

Acemoglu, D., Johnson, S., Robinson, J.A. (2001). The Colonial Origins of Comparative Development: An Empirical Investigation. The American Economic Review, 91(5), 1369-1401. doi:10.1257/aer.91.5.1369, http://dx.doi.org/10.1257/aer.91.5.1369

Alipour, H., Altinay, M., Hussain, K., Sheikhani, N. (2007). perceptions of the beach users: a case study of the coastal areas of north Cyprus towards establishment of a "carrying capacity". Tourism Analysis, 12 (3), 175-190. doi:10.3727/108354207781626785, http://dx.doi.org/10.3727/108354207781626785

Alipour, H., \& Kilic, H. (2005). An institutional appraisal of tourism development and planning: The case of the Turkish Republic of North Cyprus (TRNC). Tourism Management, 26 (1), 79-94. doi:10.1016/j.tourman.2003.08.017, http://dx.doi.org/10.1016/j.tourman.2003.08.017

Altinay, L., \& Bowen, D. (2006). Politics and tourism interface: the case of Cyprus. Annals of Tourism Research, 33 (4), 939-956. doi:10.1016/j.annals.2006.03.020, http://dx.doi.org/10.1016/j.annals.2006.03.020

Aron, J (2000). Growth and the Institutions: A Review of the Evidence. The World Rank Research Observer, 15, (1), 99-135.

Balaguer, J., \& Cantavella-Jord'a, M. (2002). Tourism as a long-run economic growth factor: the Spanish case. Applied Economics, 34, (8), $877 \quad$ - 884 doi:10.1080/00036840110058923, http://dx.doi.org/10.1080/00036840110058923

Bosselmann, K. (2008). The Principle of Sustainability: Transforming Law and Governance. Burlington: Ashgate Publishing Co.

Bryant, A., \& Charmaz, K. (2007). Grounded Theory in Historical Perspective: An Epistemological Account. In A, Bryant \& K, Charmaz (Eds.), Grounded Theory (pp. 31-57). London: Sage Publications, Inc.

Bryman, A. (2004). Social Research Methods ( $2^{\text {nd }}$. Ed.). Oxford: Oxford University Press.

Burns, P. (1999). Paradoxes in planning Tourism: Elitism or Brutalism? Annals of Tourism Research, 26 (2), 329-348. doi:10.1016/S0160-7383(98)00099-1, http://dx.doi.org/10.1016/S0160-7383(98)00099-1

Burns, P. (2004). Tourism Planning: A Third Way? Annals of Tourism Research, 31 (1), 24-43. doi:10.1016/j.annals.2003.08.001, http://dx.doi.org/10.1016/j.annals.2003.08.001

Butler, R. W. (1982). The concept of a tourist area cycle of evolution: Implications for management of resources. Canadian Geographer , 24 (1), 5-12. doi:10.1111/j.1541-0064.1980.tb00970.x, http://dx.doi.org/10.1111/j.1541-0064.1980.tb00970.x

Choi, H. C., \& Sirakaya, E. (2006). Sustainability Indicators for Managing Community Tourism. Tourism Management, $27 \quad$ (6), 27 doi:10.1016/j.tourman.2005.05.018, http://dx.doi.org/10.1016/j.tourman.2005.05.018

Collins, A., Flynn, A., Munday, M., \& Roberts, A. (2007). Assessing the Environmental Consequences of Major Sporting Events: The 2003/04 FA Cup Final .Urban Studies, 44 (3), 457-476. doi:10.1080/00420980601131878, http://dx.doi.org/10.1080/00420980601131878

Davis, J. (2001) Commentary: Tourism research and social theory - expanding the focus. Tourism Geographies, 3 (2), 125-134. doi:10.1080/14616680010030248, http://dx.doi.org/10.1080/14616680010030248

De Kadt, E. (Ed.). (1979). Tourism: Passport to Development? Oxford: Oxford University Press.

Dinica, V. (2009). Governance for sustainable tourism: a comparison of international and Dutch visions. Journal of Sustainable Tourism, 17 (5), 583 - 603. doi:10.1080/09669580902855836, http://dx.doi.org/10.1080/09669580902855836

Dodds, R. (2007). Sustainable Tourism Policy-Rejuvenation or a Critical Strategic Initiative. Anatolia: An International Journal of Tourism and Hospitality Research, 18 (2), 277-298.

Doxey, G. V. (1975). A causation theory of visitor-resident irritants, methodology and research inferences. Proceedings of the travel research association (pp.195-198). San Diego, CA: Travel and Tourism Research Association. 
Duxbury, L., \& Dickinson, S. (2007). Principles for sustainable governance of the coastal zone: In the context of coastal disasters. Ecological Economics, 63 (2-3), 319-330. doi:10.1016/j.ecolecon.2007.01.016, http://dx.doi.org/10.1016/j.ecolecon.2007.01.016

Economist (1997). Time to roll out a new model (development policy of the World Bank). March 1, 79-80.

Edgell, D.L., Allen, M.D., Smith, G., and Swanson, J.R.(2007). Tourism Policy and Planning: Yesterday, Today and Tomorrow. Oxford: Butterworth-Heinemann.

ESI. (2005). 2005 Environmental Sustainability Index: Benchmarking National Environmental Stewardship. Retrieved 12, December, 2010, from: www.yale.edu/esi

Folke, C., Hahn, T., Olsson, P., \& Norberg, J. (2005). Adaptive governance of social-Ecological systems. Annual Review of Environment and Resources, 30 (1), 441- 473. doi:10.1146/annurev.energy.30.050504.144511, $\mathrm{http}: / / \mathrm{dx}$.doi.org/10.1146/annurev.energy.30.050504.144511

Gamble, N. D., and Weil, O. M. (1997). Sustainable Development: The Challenge for Community Development. Community Development Journal, 32 (3), 210-222.

Gibson, R. B. (2000). Specification of sustainability-based environmental assessment decision criteria and implications for determining "significance" in environmental assessment. Retrieved 14, May, 2010, form: file://ff:/sustainable\%20env/sustainability-based\%20gibson\%20canada.htm

Gõssling, S., Hansson, C. B., Hõrstmeier, O., \& Saggel, S. (2002). Ecological footprint analysis as a tool to assess tourism sustainability. Ecological Economics, 43, (2-3), December 2002, 199-211. doi:10.1016/S0921-8009(02)00211-2, http://dx.doi.org/10.1016/S0921-8009(02)00211-2

Gunn, C.A., with Var, T. (2002). Tourism Planning: Basics, Concepts, Cases. $\left(4^{\text {th }}\right.$.Ed.). New York: Routledge.

Hall, M.C. (2008). Tourism Planning: Policies, Processes and Relationships. $\left(2^{\text {nd }}\right.$. Ed.). Harlow: Prentice Hall

Helmy, E. (2004). Towards Integration of Sustainability into Tourism Planning in Developing Countries: Egypt as a Case Study. Current Issues in Tourism, 7 (4), 478-501. doi:10.1080/1368350050408668199, http://dx.doi.org/10.1080/1368350050408668199

Huijbregts, M.A.J., Hellweg, S., Frischknecht, R., Hungerbühler, K.A. \& Hendriks,J.(2008). Ecological footprint accounting in the life cycle assessment of products Ecological Economics, 64 (4), 798-807. doi:10.1016/j.ecolecon.2007.04.017, http://dx.doi.org/10.1016/j.ecolecon.2007.04.017

Hunter, C., \& Shaw, J. (2007). The ecological footprint as a key indicator of sustainable tourism. Tourism Management, 28(1), pp. 46-57. doi:10.1016/j.tourman.2005.07.016, http://dx.doi.org/10.1016/j.tourman.2005.07.016

Hunter, C. (2002). Aspects of the sustainable tourism debate from a natural resources perspective. In R, Harris., T, Griffin., \& P, Williams (Eds.), Sustainable Tourism (pp.3-23). Burlington: Elsevier Butterworth-Heinemann.

Hunter, C. (1997). Sustainable tourism as an adaptive paradigm. Annals of Tourism Research, 24 (4), 850-867. doi:10.1016/S0160-7383(97)00036-4, http://dx.doi.org/10.1016/S0160-7383(97)00036-4

Jameson, K.P. (2006). Has Institutionalism Won the Development Debate? Journal of economic Issues, 40 (2), 369-375.

Jones, C., \& Munday, M. (2007). Exploring the Environmental Consequences of Tourism: A Satellite Account Approach. Journal of Travel Research, 46 (2), 164-172. doi:10.1177/0047287507299592, http://dx.doi.org/10.1177/0047287507299592

Kates, W.K., Parris, T.M., and Leiserowitz, A. A. (2005). What Is Sustainable Development? Goals, Indicators, Values, and Practice. Environment, 47 (3), 9-21.

Kaufmann, D., and Kraay, A. (2008). Governance Indicators: Where Are We, Where Should We Be Going? The World Bank Research Observer, 23 (1), 1-30. doi:10.1093/wbro/lkm012, http://dx.doi.org/10.1093/wbro/lkm012

Kemp, R., Parto, S., \& Gibson, R. B. (2005). Governance for Sustainable Development: moving form theory to practice. International Journal of Sustainable Development, 8 (1/2), 12-30. doi:10.1504/IJSD.2005.007372, http://dx.doi.org/10.1504/IJSD.2005.007372

Krajnc, D., \& Glaviĉ, P. (2005). A model for integrated assessment of sustainable development. Resources Conservation \& Recycling, 43 (2), 189-208. 
Koomian, J. (2003). Governing as Governance. London: Sage Publications. Ltd.

Lacher, H., and kaymak, E. (2005). Transforming Identities: Beyond the Politics of Non-Settlement in North Cyprus. Mediterranean Politics, 10 (2), 147-166. doi:10.1080/13629390500124341, http://dx.doi.org/10.1080/13629390500124341

Lane, B., \& Bramwell, B. (1999). Sustainable Tourism: Contributing to the Debates

.Journal of Sustainable Tourism, 7(1), 1 - 5 . doi:10.1080/096695899086667323, http://dx.doi.org/10.1080/09669589908667323

Lane, B. (1994).Sustainable rural tourism strategies: A tool for development and conservation. Journal of Sustainable Tourism, 2 (1), $102 \quad-\quad 111$ doi:10.1080/09669589409510687, http://dx.doi.org/10.1080/09669589409510687

Lee, C. C., \& Chang, C. P. (2008). Tourism development and economic growth: A closer look at panels. Tourism Management, 29 (1), 180-192. doi:10.1016/j.tourman.2007.02.013, http://dx.doi.org/10.1016/j.tourman.2007.02.013

Loomis, T. M. (2000). Indigenous Populations and Sustainable Development: Building on Indigenous Approaches to Holistic, Self-determined Development. World Development, 28 (5), 893-910. doi:10.1016/S0305-750X(99)00162-X, http://dx.doi.org/10.1016/S0305-750X(99)00162-X

Mahoney, J. (2001). Path-Dependent Explanations of Regime Change: Central America in Comparative Perspective. Studies in Comparative International Development, 36(1), 111-141. doi:10.1007/BF02687587, http://dx.doi.org/10.1007/BF02687587

Martin R., \& Sunley, P. (2006). Path dependence and regional economic evolution. Journal of Economic Geography, 6 (4), 395-437. doi:10.1093/jeg/lb1012, http://dx.doi.org/10.1093/jeg/lb1012

Mehmet, O., and Tahiroglu, M. (2002). Growth and equity in microstates: Does size matter in development? International Journal of Social Economics, 29 (1/2), 152-162. doi:10.1108/03068290210413047, http://dx.doi.org/10.1108/03068290210413047

Mehmet, O., and Yorucu, V. (2008). Explosive construction in a micro-state: environmental limit and the Bon curve: evidence from North Cyprus. Construction Management and Economics, 26 (1), 79-88. doi:10.1080/01446190701708272, http://dx.doi.org/10.1080/01446190701708272

Murray, C., and Marmorek' D. R. (2004, August). Adaptive Management: A Spoonful of Rigor Helps the Uncertainty Go Down. Submitted to the 16th International Annual Meeting of the Society for Ecological Restoration, Victoria, British Columbia, Canada.

North, D.C. (1998). Five Propositions about Institutional Change. In J. Knight \& I. Sened (Eds.), Explaining Social Institutions (pp. 15-26). Ann Arbour, MI: The University of Michigan Press.

Onga, T. (2007). The Concept of Governance: Brief Historiography. Retrieved 5, March, 2010, from: file://f:/governance/meaning\%20of\%20governance.html

Osborne, D., and Gaebler, T. (1993). Reinventing Government: How the Entrepreneurial Spirit Is Transforming the Public Sector. New York: Plume/Penguin Books.

Paul, A.D. (1994). Why Are Institutions die 'Carriers of History'? Path Dependence and die Evolution of Conventions, Organizations, and Institutions. Structural Change and Economic Dynamics, 5 (2), 205-20. doi:10.1016/0954-349X(94)90002-7, http://dx.doi.org/10.1016/0954-349X(94)90002-7

Penker, M. (2009). Landscape governance for or by the local population? A property rights analysis in Austria. Land Use Policy, 26 (4), 947-953. doi:10.1016/j.landusepol.2008.11.007, http://dx.doi.org/10.1016/j.landusepol.2008.11.007

Plumptre ,T., \& Graham, J. (1999). Governance and Good Governance: International and Aboriginal Perspectives. Retrieved 8, February, 2011, from: http://www.iog.ca/publications/govgoodgov.pdf

Pretes, M. (1995). Postmodern tourism: The Santa Claus industry. The Annals of Tourism Research, 22 (1), 1-15. doi:10.1016/0160-7383(94)00026-O, http://dx.doi.org/10.1016/0160-7383(94)00026-O

Rhodes, R.A.W. (1996). The new governance: governing without government. Political Studies, 44 (4), 652-667. doi:10.1111/j.1467-9248.1996.tb01747.x, http://dx.doi.org/10.1111/j.1467-9248.1996.tb01747.x

Rist, G. (1997). The history of development: from western origins to global faith. London: Zed Books. 
Roe, D., \& Khanya, U. (2001). Pro-Poor Tourism: Harnessing the World's Largest Industry for the World's Poor. International Institute for Environment and Development (IIED). Retrieved from www.iied.org

Sacks, J. D. (2008). Common Wealth. New York: The Penguin Press.

Segovia, V. M. (2010). Transforming Mind-sets Through Education for Sustainable Development. In P. Peterson., E. Baker. \& B. McGraw (Eds.), International Encyclopaedia of Education ( $3^{\text {rd }}$.ed). (pp. 746-752). Kidlington, U.K. Elsevier Science.

(SPO) State Planning Organization (2008). Macroeconomic and Sectoral Development -2006. (Makroekonomik ve sektörel gelişmeler). Nicosia: TRNC.

Song, Y. I., \& Glasson, J. (2010). A new paradigm for Environmental Assessment (EA) in Korea. Environmental Impact Assessment Review, $30 \quad$ (2), 90-99. doi:10.1016/j.eiar.2009.05.008, http://dx.doi.org/10.1016/j.eiar.2009.05.008

Stanhope, R. (2000). A Vision for the Future? The Concept of Sustainable Development in the Netherlands and New Zealand. New Zealand Journal of Environmental Law. 4, 147-180.

Steward, C.W., and Kuska, S. (2010). Developing and Sustaining Creative Cities: a sustainable tool for designers, planners, and public administration. International Journal of Sustainable Development, 13 (1/2), 6-16. doi:10.1504/IJSD.2010.035095, http://dx.doi.org/10.1504/JJSD.2010.035095

Tornell, A., \& Lane, P. R. (1999). The Voracity Effect. The American Economic Review, 89 (1), 22-46. doi:10.1257/aer.89.1.22, http://dx.doi.org/10.1257/aer.89.1.22

Wearing, S., and Neil, J. (2009). Ecotourism: Impacts, Potentials and Possibilities (2 ${ }^{\text {nd }}$. Ed). Amsterdam: Butterworth-Heinemann.

Webster, C., \& Timothy, D. J. (2006). Travelling to the 'Other Side': the Occupied Zone and Greek Cypriot Views of Crossing the Green Line. Tourism Geographies, 8(2), 162-181. doi:10.1080/14616680600585513, http://dx.doi.org/10.1080/14616680600585513

World Commission on Environment and Development (WCED). (1987). Our Common Future. Oxford: Oxford University Press.

World Travel \& Tourism Council (WTTC). (2004). World travel \& tourism: A world of opportunity. The 2004 travel \& tourism economic research. London: WTTC.

World Tourism Organization (WTO). (2008). World Tourism Barometer. Retrieved from www.unwto.org/infoship

World Bank. (1997). World Development Report 1997: The State in a Changing World. New York: Oxford University Press.

Yorucu, V., and Keles, R. (2007). The construction boom and environmental protection in Northern Cyprus as a consequence of the Annan Plan. Construction Management and Economics, 25 (1), 77-86. doi:10.1080/01446190600902356, http://dx.doi.org/10.1080/01446190600902356

Zhao, W., and Ritchie, J. R. B. (2007). Tourism and Poverty Alleviation: An Integrative Research Framework. In M. Hall (Ed.), Pro-Poor Tourism: Who Benefits? (pp.9-33). Toronto: Channel View Publications. 
Table 1. Tourism Share in North Cyprus's Economy (1996-2009).

\begin{tabular}{|c|c|c|c|c|c|}
\hline YEARS & $\begin{array}{l}\text { NUMBER OF } \\
\text { ARRIVALS }\end{array}$ & $\begin{array}{l}\text { NET } \\
\text { TOURISM } \\
\text { INCOME } \\
\text { (MILLION } \\
\text { USD) } \\
\end{array}$ & $\begin{array}{l}\text { THE RATIO OF NET TOURISM } \\
\text { INCOME TO THE TRADE } \\
\text { BALANCE (\%) }\end{array}$ & $\begin{array}{l}\text { OCCUPANCY } \\
\text { RATE (\%) }\end{array}$ & $\begin{array}{l}\text { NUMBER } \\
\text { TOURIST } \\
\text { ACCOMMODATIONS } \\
\text { (NUMBER OF BEDS) }\end{array}$ \\
\hline 1996 & 390,116 & 175.6 & 70.0 & 32.5 & $\mathbf{n} / \mathbf{a}$ \\
\hline 1997 & 429,364 & 183.2 & 61.3 & 35.6 & $\mathbf{n} / \mathbf{a}$ \\
\hline 1998 & 423,027 & 186.0 & 55.2 & 36.6 & 8,972 \\
\hline 1999 & 445,015 & 192.8 & 53.5 & 36.7 & 9,557 \\
\hline 2000 & 464,953 & 198.3 & $\mathbf{5 3 . 0}$ & 37.2 & 10,213 \\
\hline 2001 & 395,097 & 93.7 & 39.5 & 30.9 & 10,507 \\
\hline 2002 & 457,556 & 114.1 & 43.2 & 37.8 & 10,611 \\
\hline 2003 & 497,867 & 178.8 & 41.9 & 37.0 & 11,550 \\
\hline 2004 & 631,012 & 288.3 & 36.4 & 40.7 & 11,926 \\
\hline 2005 & 686,779 & 328.8 & 28.0 & 40.2 & 12,839 \\
\hline 2006 & 752,749 & 303.2 & 23.2 & 33.2 & 13,453 \\
\hline 2007 & 831,036 & 381,0 & 26,2 & 32.2 & 15,832 \\
\hline 2008 & 853,682 & 434,3 & 27,2 & 33,0 & 15,440 \\
\hline 2009* & 848,376 & 450,0 & 43,1 & 34,4 & 15,705 \\
\hline
\end{tabular}

Source: Ministry of Tourism, Environment and Culture (MTEC) (2008).

*Estimate.

Table 2. Coding process and categorization matrix

\begin{tabular}{|c|c|c|c|c|c|c|c|c|c|c|c|c|c|c|c|c|c|c|c|}
\hline 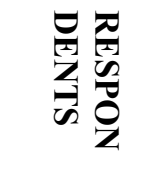 & 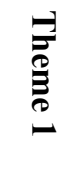 & 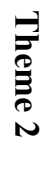 & $\underset{\bar{\sigma}}{\vec{E}}$ & $\begin{array}{l}\bar{\Xi} \\
\bar{\Xi} \\
\bar{\Xi} \\
\stackrel{+}{+}\end{array}$ & 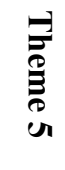 & 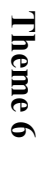 & 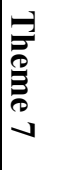 & $\begin{array}{l}\overrightarrow{1} \\
\bar{\sigma} \\
\overline{0} \\
0 \\
\infty\end{array}$ & 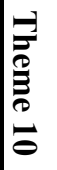 & 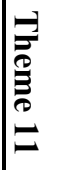 & 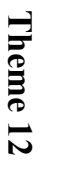 & 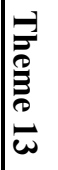 & 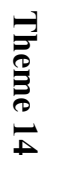 & $\frac{\vec{\partial}}{\stackrel{0}{0}}$ & $\begin{array}{l}\overrightarrow{0} \\
\stackrel{0}{0} \\
\frac{0}{\sigma}\end{array}$ & $\frac{7}{\overrightarrow{0}}$ & $\frac{\vec{\sigma}}{\stackrel{0}{\frac{0}{2}}}$ & $\frac{\overline{0}}{\stackrel{0}{0}}$ & 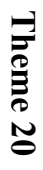 \\
\hline 1 & $\checkmark$ & $\checkmark$ & & $\checkmark$ & & $\checkmark$ & & & $\checkmark$ & & $\checkmark$ & & $\checkmark$ & $\checkmark$ & & $\checkmark$ & & $\checkmark$ & $\checkmark$ \\
\hline 2 & & & $\checkmark$ & $\checkmark$ & $\checkmark$ & & $\sqrt{ }$ & $\checkmark$ & & $\checkmark$ & & & & & $\checkmark$ & $\checkmark$ & & $\checkmark$ & $\sqrt{ }$ \\
\hline 3 & $\checkmark$ & & $\sqrt{ }$ & & & $\sqrt{ }$ & & & & $\sqrt{ }$ & & & $\checkmark$ & & $\checkmark$ & $\checkmark$ & & $\checkmark$ & $\sqrt{ }$ \\
\hline 4 & & $\checkmark$ & & & $\checkmark$ & $\checkmark$ & & $\checkmark$ & $\checkmark$ & & & & & & $\checkmark$ & & $\checkmark$ & . & \\
\hline 5 & $\checkmark$ & & & $\checkmark$ & $\checkmark$ & $\sqrt{ }$ & $\sqrt{ }$ & & $\checkmark$ & & $\checkmark$ & $\checkmark$ & $\checkmark$ & $\checkmark$ & & $\checkmark$ & $\checkmark$ & & $\sqrt{ }$ \\
\hline 6 & & $\checkmark$ & $\sqrt{ }$ & $\checkmark$ & & $\sqrt{ }$ & $\checkmark$ & & & & $\checkmark$ & $\checkmark$ & & & & $\checkmark$ & $\sqrt{ }$ & $\checkmark$ & $\sqrt{ }$ \\
\hline 7 & $\checkmark$ & & & & $\checkmark$ & & & & $\checkmark$ & $\checkmark$ & & & $\checkmark$ & $\checkmark$ & $\checkmark$ & $\checkmark$ & & & $\checkmark$ \\
\hline 8 & $\checkmark$ & & $\checkmark$ & $\checkmark$ & & $\checkmark$ & $\checkmark$ & $\checkmark$ & & $\checkmark$ & & & & & $\checkmark$ & $\checkmark$ & $\checkmark$ & & \\
\hline 9 & & $\checkmark$ & & $\checkmark$ & $\checkmark$ & & & & $\checkmark$ & & & $\checkmark$ & $\checkmark$ & $\checkmark$ & & & & $\checkmark$ & $\checkmark$ \\
\hline 10 & $\checkmark$ & & $\checkmark$ & $\checkmark$ & & $\checkmark$ & $\checkmark$ & $\checkmark$ & $\checkmark$ & & $\checkmark$ & & $\checkmark$ & & & $\checkmark$ & $\checkmark$ & $\checkmark$ & $\sqrt{ }$ \\
\hline 11 & & & $\sqrt{ }$ & $\checkmark$ & $\checkmark$ & $\checkmark$ & $\sqrt{ }$ & & & $\checkmark$ & & & $\checkmark$ & & $\checkmark$ & $\checkmark$ & & & $\sqrt{ }$ \\
\hline 12 & & $\checkmark$ & $\checkmark$ & $\checkmark$ & $\checkmark$ & $\checkmark$ & 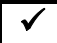 & $\checkmark$ & & & & & $\checkmark$ & $\checkmark$ & $\checkmark$ & $\checkmark$ & & & $\checkmark$ \\
\hline 13 & $\checkmark$ & & $\checkmark$ & & & & & & & & $\checkmark$ & & & & & & & & $\checkmark$ \\
\hline 14 & $\checkmark$ & & $\checkmark$ & & & & & $\checkmark$ & & & & & & & & & $\checkmark$ & & $\checkmark$ \\
\hline 15 & & $\checkmark$ & $\checkmark$ & & & & & $\checkmark$ & & & & & $\checkmark$ & & & & $\checkmark$ & & $\checkmark$ \\
\hline $\begin{array}{l}\text { TOTAL } \\
\text { HITS/C } \\
\text { OMME } \\
\text { NTS } \\
\text { ON } \\
\text { THE } \\
\text { THEM } \\
\text { E. }\end{array}$ & 8 & 6 & 10 & 9 & 7 & 9 & 7 & 7 & 6 & 5 & 5 & 3 & 9 & 5 & 7 & 10 & 7 & 6 & 13 \\
\hline
\end{tabular}




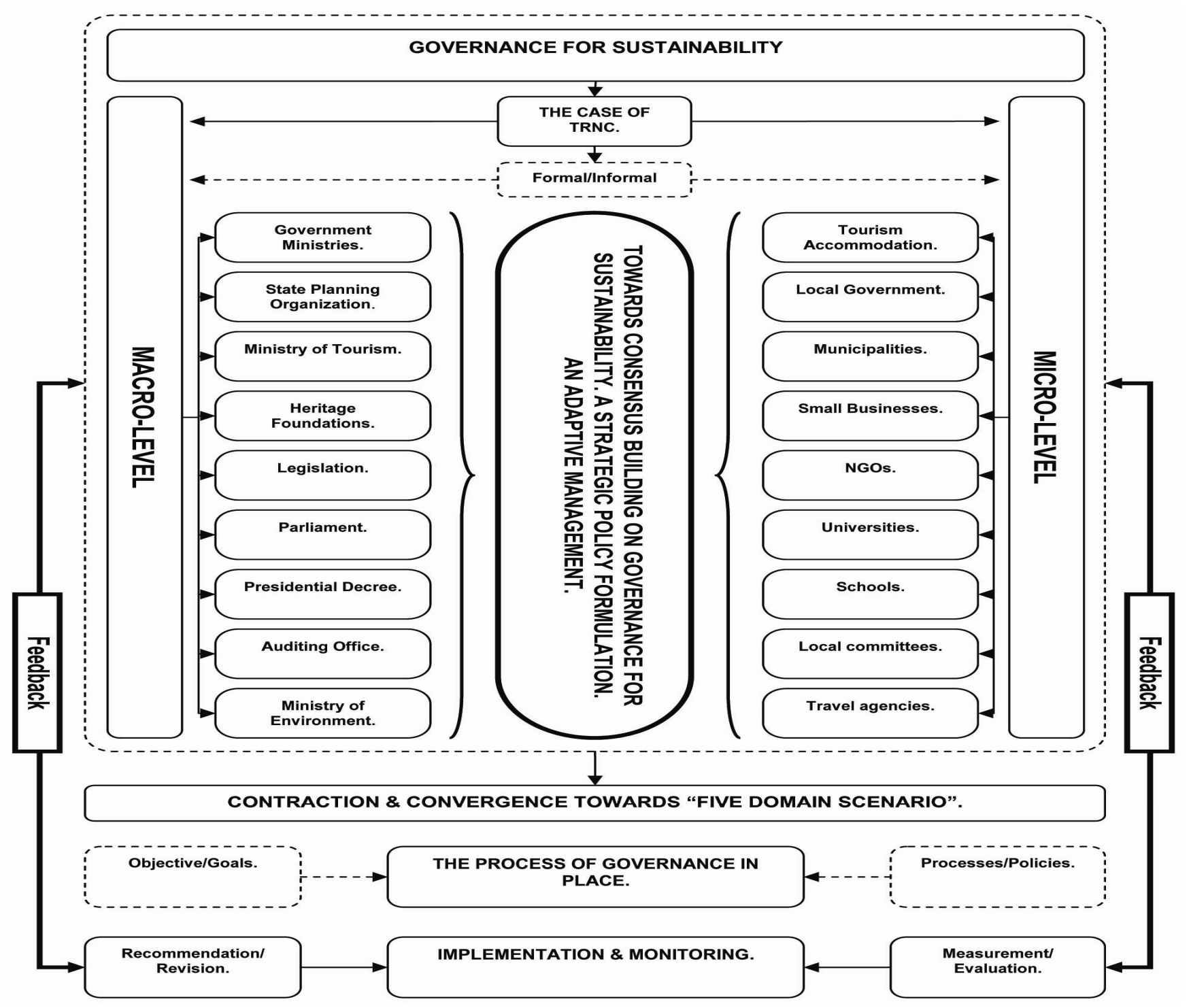

Figure 1. Governance for Sustainability Model 


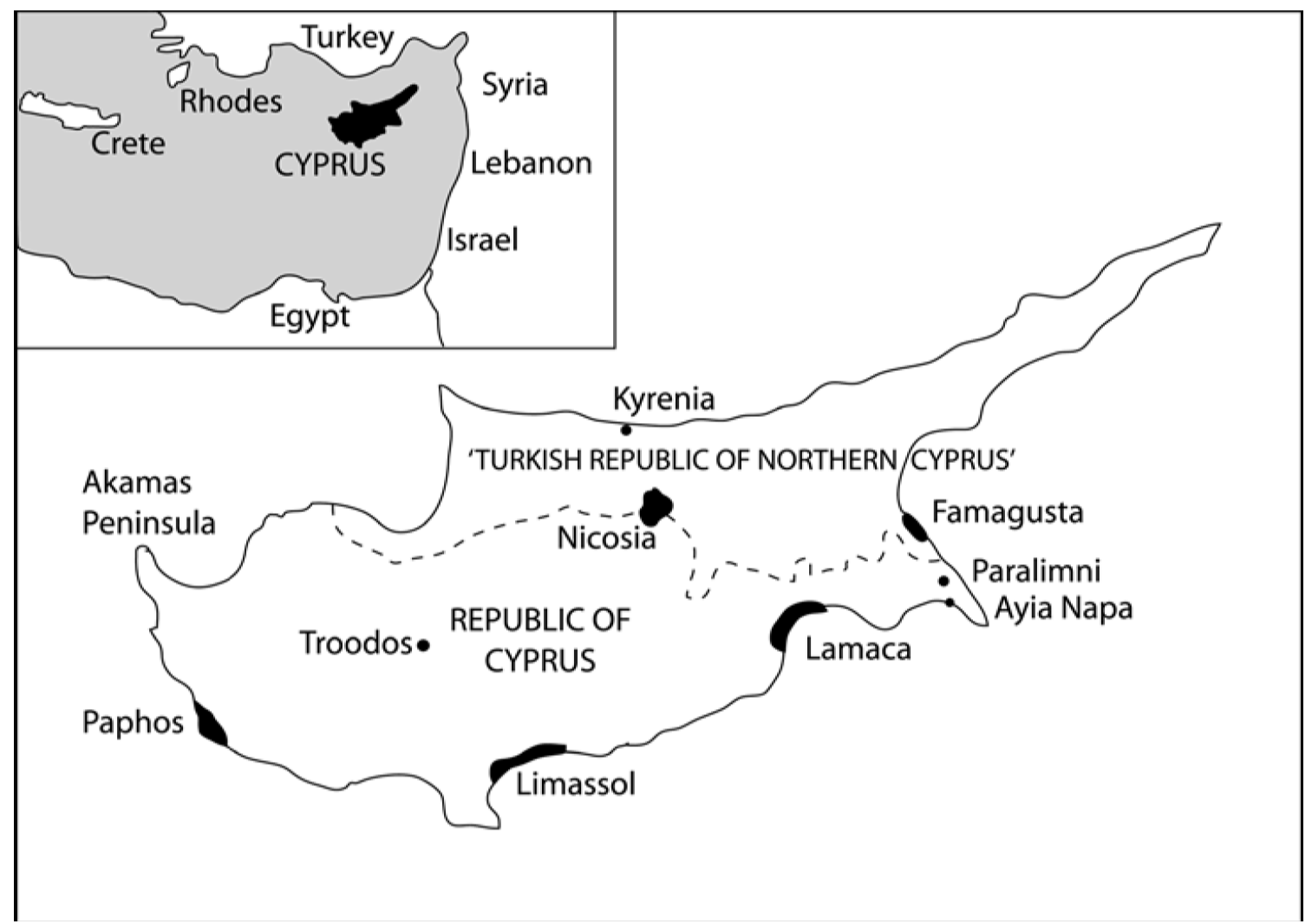

Figure 2. The map of Cyprus with demarcation line 


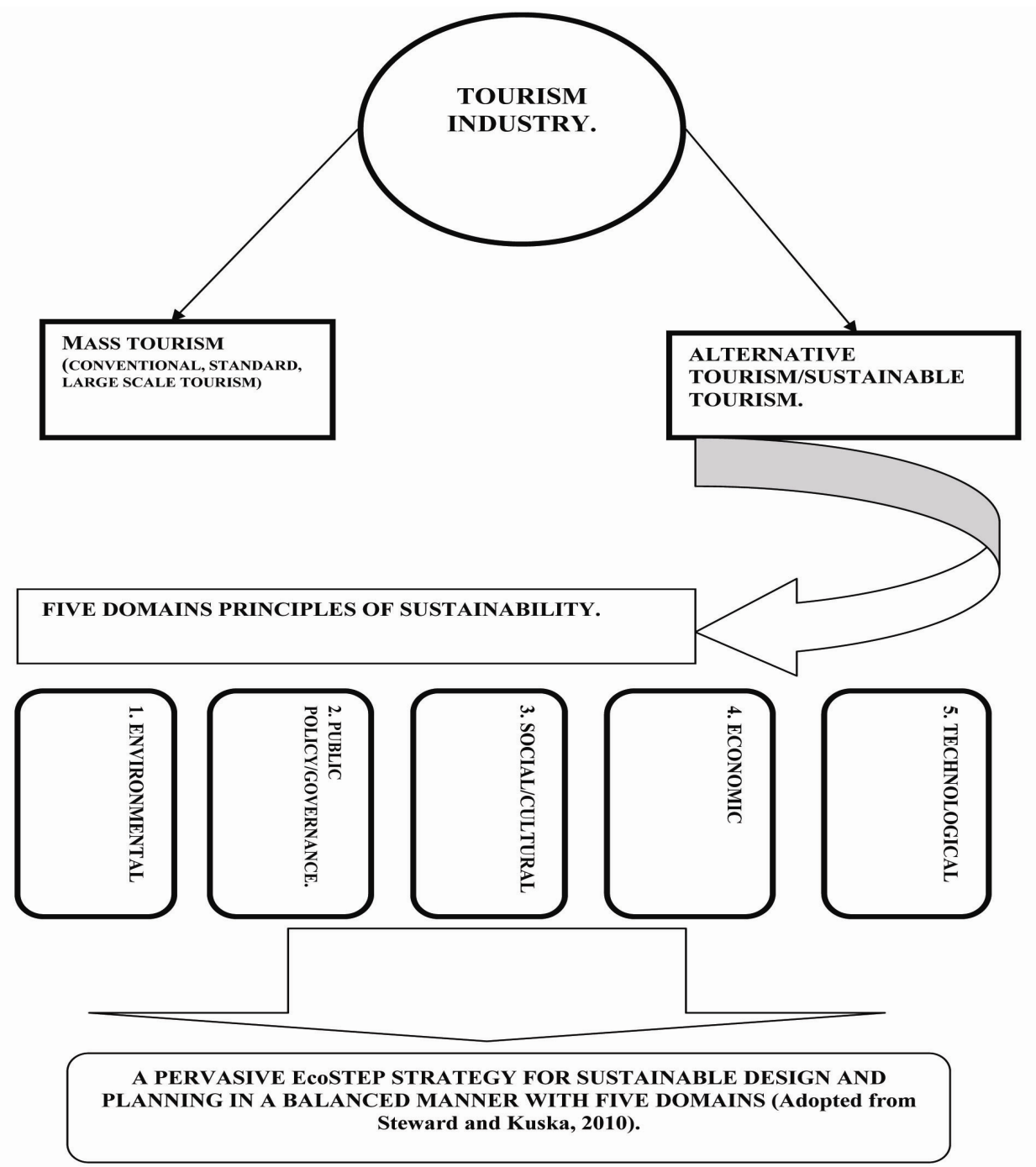

Figure 3. Analytical Framework Model 


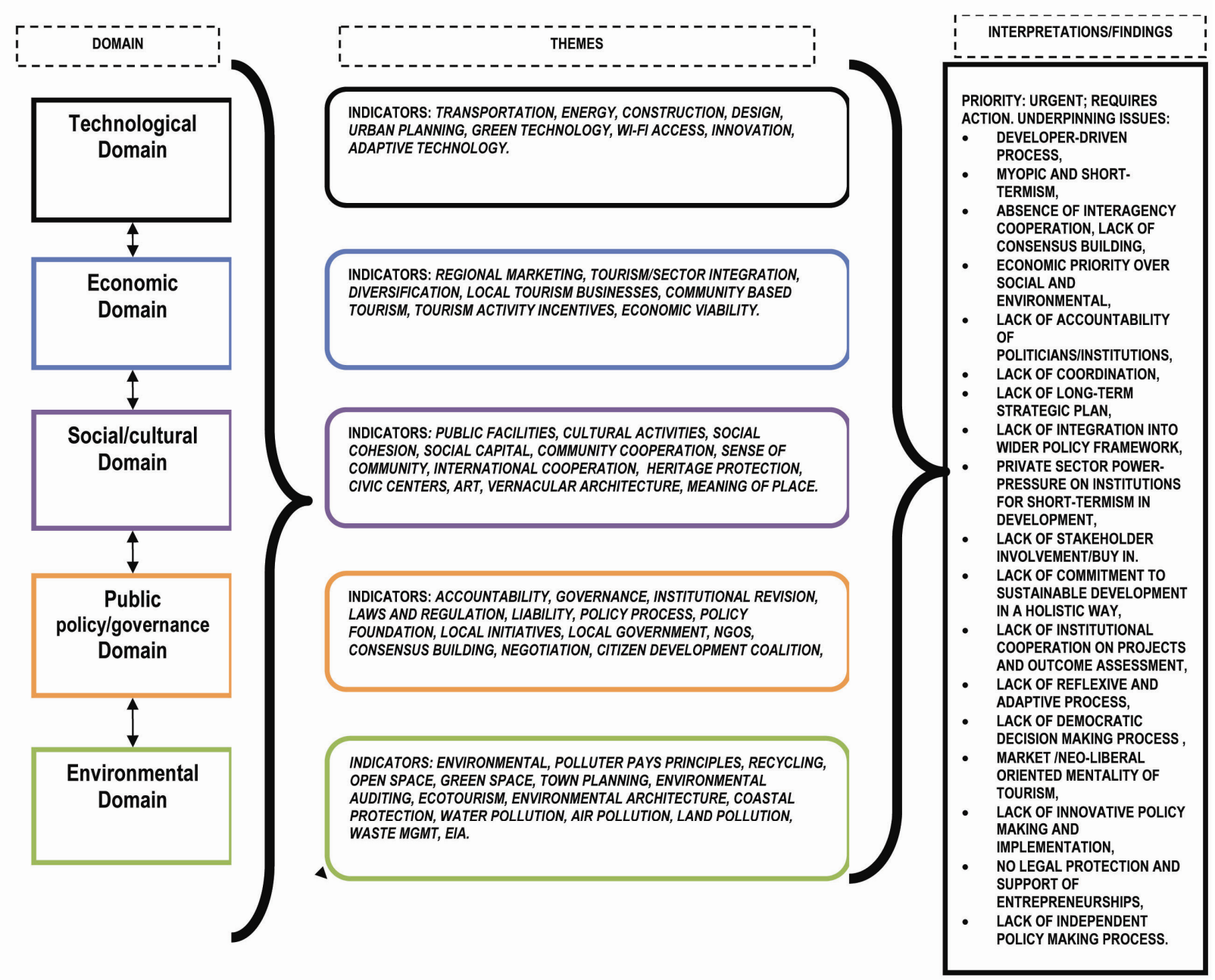

Figure 4. Data Analysis Matrix 